\title{
MENGULIK PENGEMBANGAN NASIONALISME GENERASI MUDA DI ERA GLOBALISASI
}

\author{
AMRAH \\ Prodi PGSD Fakultas Ilmu Pendidikan UNM
}

\begin{abstract}
ABSTRAK
Rasa nasionalisme sangat penting sekali bagi generasi muda Indonesia untuk bisa menjadi bangsa yang maju, bangsa yang moderen, bangsa yang aman, dan damai, adil dan sejahtera di tengahtengah arus globalisasi yang semakin hari semakin menantang negara Indonesia. Sebagai bangsa dan negara di tengah bangsa lain di dunia membutuhkan identitas kebangsaan (Nasionalisme) yang tinggi dari warga negara khususnya di kalangan generasi muda Indonesia. Semangat nasionalisme dibutuhkan tetap eksisnya bangsa dan negara Indonesia. Nasionalisme yang tinggi dari warga negara atau generasi muda sehingga akan membuat perilaku positif dan terbaik untuk bangsa dan negara. Dalam dekade, ada beberapa kecenderungan menipisnya jiwa nasionalisme dikalangan generasi muda. Hal ini dapat diliahat dari beberapa tolak ukur yaitu kurang apresiasinya generasi muda terhadap kebudayaan asli Indonesia, pola dan gaya hidup remaja yang kebarat-baratan, dan sebagainya.
\end{abstract}

Kata Kunci: nasionalisme, generasi muda, globalisasi

\section{PENDAHULUAN}

Di era globalisasi sekarang ini, sudah semakin berkembang teknologi informasi yang telah mengakibatkan kaburnya batas-batas antar negara (baik secara politik, ekonomi, maupun sosial), masalah nasionalisme tidak lagi dapat dilihat sebagai masalah sederhana yang dapat dilihat dari satu perspektif saja. Masalah pembangunan nasionalisme di Indonesia saat ini tengah menghadapi tantangan yang berat. Di tengah situasi bangsa Indonesia yang seperti itu, nasionalisme sangat di butuhkan untuk menjaga Negara Kesatuan Republik Indonesia.

Teknologi internet merupakan teknologi yang memberikan informasi tanpa batas dan dapat diakses oleh siapa saja. Apa lagi bagi anak muda internet sudah menjadi santapan mereka sehari- hari. Jika digunakan secara semestinya tentu kita memperoleh manfaat yang berguna. Tetapi jika tidak, kita akan mendapat kerugian. Dan sekarang ini, banyak pelajar dan mahasiswa yang menggunakan tidak semestinya. Misal untuk membuka situs-situs porno. Bukan hanya internet saja, ada lagi pegangan wajib mereka yaitu handphone. Rasa sosial terhadap masyarakat menjadi tidak ada karena mereka lebih memilih sibuk dengan menggunakan handphone.

Refleksi kisah perjuangan telah terbukti betapa tinginya semangat perjuangan Bangsa Indonesia untuk mengusir dan melawan penjajah sejak awal penjajahan Belanda sampai dengan tercapai Kemerdekaan Republik Indonesia. Dimana generasi yang lebih tua agar mewariskan tidak hanya pengetahuan tentang tonggak sejarah atas kejadian yang terjadi di masa lalu namun juga terutama tentang semangat nasionalisme yang berpengaruh atas perjalanan hidup dalam berbangsa dan bernegara. Karena dengan demikian akan tercipta suatu hubungan emosional secara timbal-balik di antaranya dalam kaitan semangat nasionalisme. Hal ini menjadi sebuah tuntutan yang layak, agar generasi muda dapat menghargai jasa-jasa Pejuang dan Pahlawannya sehingga mereka menempatkan para Pejuang dan Pahlawan yang terhormat.

Bangsa indonesia adalah bangsa yang kaya akan budaya, suku, ras, dan agama. Hal ini sangat berkaitan dengan jiwa nasionalisme generasi penerus bangsa indonesia. Barbagai masalah yang dihadapi oleh bangsa indonesia mulai dari masalah kemiskinan, pengangguran dan terorisme, sehingga menimbulkan banyak problem. Salah satunya ialah minimnya rasa nasionalisme generasi muda. Hal ini tidak bisa dipungkiri karena masyarakat lebih memilih untuk kelangsungan hidupnya daripada memikirkan untuk negara. Tinggi atau rendahnya rasa nasionalisme generasi muda saat sekarang ini salah satunya dipenagaruhi oleh budaya-budaya barat yang dengan mudahnya masuk dan mempengaruhi budaya 
bangsa indonesia yang pada hakekatnya adalah jati diri budaya Timur. Rasa nasionalisme sangat penting sekali bagi generasi muda indonesia untuk bisa menjadi bangsa yang maju, bangsa yang moderen, bangsa yang aman, dan damai, adil dan sejahtera di tengahtengah arus globalisasi yang semakin hari semakin menantang negara indonesia.

Pada masa penjajahan Belanda, bangsa indonesia mencapai puncak kejayaan rasa nasionalisme, dimana pejuang-pejuang terdahulu bersatu dari sabang sampai merauke untuk membebaskan diri dari belenggu penjajahan. Hal itulah bisa terwujud rasa nasionlaisme yang tinggi di masyarakat indonesia dan telah terbukti kita memproklamasikan kemerdekaan republik indonesia dengan semangat perjuangan yang cukup tinggi.

Selama ini, pendidikan menitik beratkan pada pengisian kognitif semata sisi afektif emosional dan kecerdasan spriritual kurang diperhatikan dan seolah tidak menjadi garapan pendidikan. Masayarakat menggap bahwa orang yang cerdas ialah mereka yang mampu menghapal banyak rumus, menguasai bahasa asing dengan fasih, dan mampu menjawab soal pelajaran secara tepat dan cermat. Akibatnya dunia pendidikan hanya memproduksi orang yang cerdas otak. Padahal, tujuan pendidikan yang tertuang dalam UUD 1945 aialah mencerdaskan kehidupan bangsa. Semnatara yang impelmentasinya pendidikan hanya mencerdaskan otak, bukan mencerdaskan kehidupan, sehingga selama ini pendidikan banyak memproduksi intelektual yakni orang yang memiliki otak yang cerdas dan cemerlang.

Jika dihapkan pada perkembangan di era globalisasi yang merupakan suatu proses menjadikan sesuatu sebagai ciri dari setiap individu di dunia ini tanpa dibatasi oleh wilayah. Tetapi para globis pesimis berpendapat bahawa globalisasi adalah sebuah fenomena negatif karena hal tersebut adalah bentuk penjajahan Barat (Amerika Serikat) yang memaksa sejumlah budaya dan komsumsi yang homogen dan terlihat sebagai sesuatu yang benar dipermukaan. Sekarang ini terkadang globalisasi tidak tersaring, ketergantungan dengan teknologi, pemborosan pengeluaran dan meniru perilaku yang buruk, mudah terpengaruh oleh hal yang tidak sesuai dengan kebiasaan atau kebudayaan suatu negara khususnya untuk para generasi muda indonesia.

\section{KAJIAN PUSTAKA \& PEMBAHASAN}

\section{A. Konsep Nasionalisme}

Globalisasi telah mengubah segalanya, aktivitas bahkan karakter manusia pun dirubahnya, termasuk nasionalimse generasi muda. Semakin majunya arus globalisasi membuat rasa cinta dan bangga terhadap budaya semakin berkurang, sehingga lama-kelamaan, rasa bangga terhadap budaya sendiri bisa menghilang dan menurunkan kurangnya rasa memiliki terhadap bangsa sendiri. hal ini sangat berdampak negatif bagi jiwa nasionalisme generasi muda asli indonesia.

Nasionalisme berasal dari kata nation yang berarti bangsa. Menurut Kamus Besar Bahasa Indonesia (Ali, 2011:89) kata bangsa memiliki arti:

(1) kesatuan orang yang bersamaan asal keturunan, adat, bahasa, dan sejarahnya serta pemerintahan sendiri;

(2) golongan manusia, binatang, atau tumbuh-tumbuhan yang mempunyai asal-usul yang sama dan sifat khas yang sama atau bersamaan; dan

(3) kumpulan manusia yang biasanya terikat karena kesatuan bahasa dan kebudayaan dalam arti umum, dan yang biasanya menempati wilayah tertentu di muka bumi. Beberapa makna kata bangsa diatas menunjukkan arti bahwa bangsa adalah kesatuan yang timbul dari kesamaan keturunan, budaya, pemerintahan, dan tempat. Pengertian ini berkaitan dengan arti kata suku yang dalam kamus yang sama diartikan sebagai golongan orang-orang (keluarga) yang seturunan; golongan bangsa sebagai bagian dari bangsa yang besar.

Sedangakan Dault (2003: 3) mengatakan bahwa: "bangsa mempunyai dua pengertian yaitu pengertian antropologis- sosiologis dan pengertian politis. Menurut pengertian antrososiologis, bangsa adalah suatu masyarakat yang merupakan persekuatuan hidup yang berdiri sendiri dan masing-masing anggota masyarakat tersebut merasa satu kesatuan suku, bahasa, agama, sejarah, dan adat-istiadat".

Nur (2001:57-58) mengatakan bahwa dalam pengertian politis "bangsa adalah masyarakat dalam suatu daerah yang sama dan mereka tunduk kepada kedaulatan negaranya sebagai suatu kekuasaan tertinggi di luar dan 
ke dalam". Bangsa (nation) dalam pengertian politik inilah yang kemudian menjadi pokok pembahasan nasionalisme. Istilah nasionalisme yang telah diserap ke dalam bahasa indonesia memiliki dua pengertia yaitu paham atau ajaran untuk mencintai bangsa dan negara sendiri dan kesadran keanggotaan dalam suatu bangsa yang secara potensial atau aktual bersama-sama mencapai, mempertahankan, dan mengabdikan identitas, integritas, kemakmuran, dan kekuaran bangsa itu.

Dengan pengertian nasionalisme di atas dapat dipahami bahwa nasionalisme berarti menyatakan keunggulan suatu afinitas kelompok yang didasarkan atas kesamaan bahasa, budaya, dan wilayah.

\section{B. Paradigma Nasionalisme Bangsa Indonesia}

Sumber dari kekuatan ideologi nasionalis saat ini memang belum ditemukan oleh banyak orang Indonesia sehingga ketika kita mencari arus apa yang seharusnya berada di depan kita sebagai energi yang menuntun kemajuan nasional negara dan masyarakat kita seringkali bimbang dan gelap. Oleh karena itu untuk menjawab tantangan ini sebuah organisasi politik harus mampu menemukan sumber ideologi nasionalisme. Sekaligus mampu menggerakkan menjadi kekuatan utama dalam pencapaian tujuan politiknya. Sebenarnya sangat mudah kita temukan di mana sumber ideologi tersebut jika kita telah mencapai kesadaran penuh dengan kualitas yang sehat. Karena ideologi nasionalisme itu bersumber pada mainstream persatuan dan kesatuan.

Namun, pemahaman akan persatuan dan kesatuan sering kali menjadi kesalahan dalam ide dan prakteknya sehingga ketika kita berbicara tentang nilai tersebut kita tidak mampu mengambil kekuatan intinya. Persatuan dan Kesatuan memiliki arti independen organik, atau sosial liberal dalam konteks manifestasinya. Independen organik ini berarti sebuah penyatuan sosial secara individual dan kolektif Ketika kita sebagai manusia tersadarkan melalui nalar, perasaan, dan gerakan kemanusiaan untuk suatu keadilan, kemakmuran, dan kemajuan. Dari sumber kekuatan nasionalisme ini kita akan bergerak ke arah revolusi nasional sebagai gerakan perlawanan terhadap kejahatan dan ketidakadilan sistem yang mengatur manusia untuk kepentingan nafsu dan syahwat. Namun, dalam memaknai revolusi kita harus menyadari juga bahwa revolusi nasionalisme yang dimaksud di sini bukanlah revolusi berdarah yang menghadirkan konflik dan perpecahan nasional, karena kembali pada sumber ide nasionalisme itu sendiri yaitu "persatuan dan kesatuan".

Tamburaka (1999: 173-176) mengatakan bahwa nasionalisme indonesia mebagi tiga corak kepada filsafat sejarah yaitu:

1. Yang menjadi objek tafsiran ialah sejarah nasional indonesia, yang berbeda cara menulis daripada indonesia sebelum proklamsi, karena yang menjadi dasar kepada penulisan sejarah indonesia sesudah tahun 1945 ialah adanya kemerdekaan bangsa indonesia yang menjadi syarat mutlak bagi segala ilmu pengetahuan yang dikembangkan oleh hikmah manusia bebas.

2. Cara menasfsirkan kejadian sejarah adalah sesuai dengan jalan pikiran orang bangsa indonesia yang telah bebas merdeka, dan yang tak tertarik rasa rendah atau berpandangan sempit di dalam ruangan pikiran yang terbatas.

3. Uraian dengan lisan atau menuliskan sejarah indonesia memenuhi syarat insan para pengarang supaya secara subyektif sesuai dengan susila perjuangan kemerdekaan: memenuhi syarat susila pada karangan penulisan sejatah dan memenuhi syarat ilmu jiwa dan pendidikan pada pembaca dan si pendengar, supaya rasa nasionalisme indonesia merdeka menjadi kebanggaan bangsa yang jangan mudah tersinggung, malahan supaya menjadikan sejarah indonesia sumber inspirasi dan ilmu pengetahuan untuk kehidupan bangsa yang ingin berijwa besar dan luas.

Sebagai bangsa dan negara di tengah bangsa lain di dunia membutuhkan identitas kebangsaan (nasionalisme) yang tinggi dari warga negara indonesia. Semangat nasionalisme dibutuhkan tetap eksisnya bangsa dan negara indonesia. Nasionalisme yang tinggi dari warga negara sehingga akan membuat perilaku positif dan terbaik untuk bangsa dan negara. Dalam dekade, ada beberapa kecenderungan menipisnya jiwa nasionalisme dikalangan generasi muda. Hal ini dapat diliahat dari beberapa tolak ukur yaitu kurang apresiasinya generasi muda terhadap kebudayaan asli indonesia, pola dan gaya 
hidup remaja yang kebarat-baratan, dan sebagainya.

Tidak semua nilai global harus diterima dan tidak semua niali-nilai tradisional bangsa harus ditinggalkan. Seperti nilai-nilai bangsa yang mengedepankan musyawarah, kerjasama, gotong royong, dan saling membantu tetap relevan dalam meyelematkan generasi muda dimasa yang akan datang ditengah kehidupan global yang membawa nilai-nilai yang bisa merongrong identitas nasional bangsa indonesia.

\section{Nasionalisme Pancasila sebagai Falsafah Hidup Bangsa Indonesia}

Pada prinsipnya nasionalisme Pancasila adalah pandangan atau paham kecintaan manusia Indonesia terhadap bangsa dan tanah airnya yang didasarkan pada nilainilai Pancasila. Prinsip nasionalisme bangsa Indonesia dilandasi nilai-nilai Pancasila yang diarahkan agar bangsa Indonesia senantiasa:

1. Menempatkan persatuan-kesatuan, kepentingan dan keselamatan bangsa dan negara di atas kepentingan pribadi atau kepentingan golongan

2. Menunjukkan sikap rela berkorban demi kepentingan bangsa dan negara

3. Bangga sebagai bangsa Indonesia dan bertanah air Indonesia serta tidak merasa rendah diri

4. Mengakui persamaan derajat, persamaan hak dan kewajiban antara sesama manusia dan sesama bangsa

5. Menumbuhkan sikap saling mencintai sesama manusia

6. Mengembangkan sikap tenggang rasa

7. Tidak semena-mena terhadap orang lain

8. Gemar melakukan kegiatan kemanusiaan

9. Senantiasa menjunjung tinggi nilai kemanusiaan

10.Berani membela kebenaran dan keadilan

11. Merasa bahwa bangsa Indonesia merupakan bagian dari seluruh umat manusia

12.Menganggap pentingnya sikap saling menghormati dan bekerja sama dengan bangsa lain (Yatim, 2001:164).

Di indonesia, nasionalisme melahirkan pancasila sebagai ideologi negara. Perumusan pancasila sebagai ideologi negara terjadi dalam sidang BPUPKI (Badan Penyidik
Usaha-usaha Persiapan Kemerdekaan Indonesia).

Jalaluddin dan Idi (2011: 167) mengatakan bahwa "pancasila ialah jiwa dan seluruh rakyat indonesia, kepribadian bangsa indonesia, pandangan bangsa indonesia, dan dsaar negara". Disamping menjadi tujuan hidup bangsa indonesia, pancasila juga merupakan kebudayaan yang mengajarkan bahwa hidup manusia akan menjadi puncak kebahagiaan jika dapat dikebamgkan keselarasan dan keseimbangan, baik dalam hidup manusia sebagai pribadi, sebagai mahkluk sosial dalam mengejar hubungan dalam masyarakat, alam, Tuhannya maupun dalam mengejar kemauan lahiriah dan kebahagiaan rohaniah.

Tamburka (1999: 263-264) mengatakan bahwa pancasila sebagai pandangan hidup bangsa indonesia menjadi landasan filosofis, guna membangun diri, masyarakat, bangsa dan negara memeiliki silasila yang mempunyai makna sebagai berikut:

1. Ketuhan Yang Maha Esa merupakan landasan bangsa indonesia dalam kehidupan ber-Tuhan dan beragama.

2. Sila Kemanusiaan yang adil dan berdadab merupakan landasan dalam rangaka meningkatkan harkat dan martabat manusia yang mencerminkan tidak adanya eksploitasi terhadap manusia lain secara universal.

3. Sila Persatuan Indonesia merupakan landasan "National Character Building", sehingga tumbuh indonesia yang beramor patria, bersosial budaya indonesia.

4. Sila kerakyatan yang dipimpin oleh hikmah kbijaksanaan dalam permusyawaratan perwakilan merupakan landasan dalam pembangunan demokrasi politik indonesia.

5. Sial keadilan sosial bagi seluruh rakyat indonesia merupakan landasan demokrasi ekonomi indonesia.

Sedangkan Kaelan (2010: 15) mengatakan bahwa pendidikan pancasila bertujuan untuk menghasilkan peserta didik yang berprilaku:

a. Memiliki kemampuan untuk mengambil sikap yang bertanggung jawab sesuai dengan hati nuraninya.

b. Memiliki kemampuan untuk mengenali masalah hidup dan kesejahteraan serta cara-cara pemecahannya, dan 
c. Memiliki kemmapuan untuk memaknai peristiwa sejarah dan nilai-nilai budaya bangsa yang untuk menggalang persatuan indonesia.

Nilai-nilai tersebut di atas sangat dibutuhkan dalam mengahadapi era globalisasi saat ini, karena tanpa penghambatan terhadap Tuhan manusia tidak akan menjadi manusia sesungguhnya. Manusia yang tidak sesungguhnya tidak menghendaki persatuan diamna jaringan kerja sangat diperlukan dalam menghadapi persaingan bebas apalagi isu Masyarakat Ekonomi Asean (MEA) sudah di depan mata.

Hal yang sama juga dikemukakan Jaladuddin dan Idi (2011: 168) bahwa sangatlah wajar kalau pancasila dikatakan sebagai falsafah bangsa, nilai-nilai dasar sosio budaya indonesia hidup dan berkembang sejak awal perabadannya, yaitu sebagai berikut:

1. Kesadaran ketuhanan dan kesadaran keagamaan secara sederhana.

2. Kesadaran kekeluargaan, dimana cinta dan keluarga sebagai dasar dan kodrat terbentuknya masyarakat sinambungnya generasi.

3. Kesadaran musyawarah mufakat dalam menetapkan kehendak bersatu.

4. Kesadaran gotong royong, dan tolong menolong.

5. Kesadaran tenggang rasa sebagai semangat kekeluargaan dan kebersamaan, hormat menghormati dan memelihara kesatuan, saling pengertian, kerukunan dan kekeluargaan dalam kebersamaan.

\section{Konsep Globalisasi di kalangan Genersi Muda}

Arus globalisasi begitu cepat merasuk ke dalam masyarakat terutama di kalangan muda. Pengaruh globalisasi terhadap anak muda juga begitu kuat. Pengaruh globalisasi tersebut telah membuat banyak anak muda kita kehilangan kepribadian diri sebagai bangsa Indonesia. Hal ini ditunjukkan dengan gejala- gejala yang muncul dalam kehidupan sehari- hari anak muda sekarang.

Dilihat dari sikap, banyak anak muda yang tingkah lakunya tidak kenal sopan santun dan cenderung cuek tidak ada rasa peduli terhadap lingkungan. Karena globalisasi menganut kebebasan dan keterbukaan sehingga mereka bertindak sesuka hati mereka. Contohnya adanya geng motor atau begal motor anak muda yang melakukan tindakan kekerasan yang menganggu ketentraman dan kenyamanan masyarakat. Jika pengaruhpengaruh di atas dibiarkan, maka moral generasi bangsa menjadi rusak dan akan timbul tindakan anarkis antara golongan muda. Hubungannya dengan nilai nasionalisme akan berkurang karena tidak ada rasa cinta terhadap budaya bangsa sendiri dan rasa peduli terhadap masyarakat.

Sekaitan dengan problem di atas perlu dipahami bahwa arti dari globalisasi itu sendiri dari kata "global" yang maknanya universal. Menuru Suparman globalisasi ialah suatu proses menjadikan sesuatu sebagai ciri dari setiap individu di dunia ini tanpa batas oleh wilayah globalisasi. Disisi lain ada yang melihat globalisasi sebagai sebuah proyek yang usung oleh negara-negara adikuasa, sehingga bisa saja orang memiliki pandangan negatif atau curiga terhadap globalisasi. Dari sudut pandang ini, globalisasi tidak lain yaitu saatu kapitalisme dalam bentuk yang paling mutakhir. Negara-negara yang kuat dan kaya praktis akan mengendalikan ekonomi dunia dan negara-negara kecil makin tida berdaya karena tidak mampu bersaing. Karena, globalisasi cenderung berpengaruh besar terhadap perekonomian dunia bahkan berpengaruh terhadap bidang-bidang lain misalnya bidang agama dan budaya.

Ada beberapa defenisi globalisasi menurut Idi (2011:214) adalah sebagai berikut:

a. Internalisasi

Globalisasi diartikan sebagai

meningkatnya hubungan internasional.

Dalam hal ini masing-masing negara tetap mempertahankan identitasnya masing-masing, namun menjadi semakin tergantung sama lain.

b. Liberalisasian

Globalisasi diartikan sebagai semakin diturunkan batas antar negara, seperti hambatan tarif ekspor dan impor, lalu lintas devisa, maupun migrasi.

c. Universalisasi

Globalisasi diartikan sebagai semakin tersebarnya hal material maupun imaterial ke seluruh dunia.

d. Weternisasi

Weternisasi adalah sebuah bentuk dari universalisasi dengan semakin menyebarnya pikiran dan budaya dari barat sehingga mengglobal.

e. Hubungan transplanetari dan suprateritorialita 
Arti kelima ini berbeda dengan keempat defenisi di atas. Pada empat defenisi pertama masing-masing negara masih mempertahankan status ontologinya. Pada pengertian yang kelima ini dunia global memiliki status ontologi sendiri, bahkan sekedar gabungan negara-negara.

Unsur-unsur globalisasi yang sukar diterima masyarakat yaitu: unsur budaya yang sukar disesuaikan dengan kondisi dan kemmapuan masyarakat, teknologi yang rumit dan mahal harganya, unsur budaya luar yang menyangkut paham ideologi poltik keagamaan, unsur globalisasi yang mudah diterima masyarakat yaitu: globalisasi yang mudah disesuakian dengan kebuuthan dan kondisi masyarakat.

Menurut Kazikame (2013) dampak positif dan negatif era globalisasi bagi kehidupan kita:

1. Dampak Positif

a. Perubahan Tata Nilai dan Sikap Adanya globalisasi dalam budaya menyebabkan pergeseran nilai dan sikap masyarakat yang semua irasional menjadi rasional dengan meningkatkan etos kerja yang tinggi, suka bekerja keras, disiplin, mempunyai jiwa kemandirian, rasional, sportif, dan lain sebagainya.

b. Berkembangnya ilmu pengetahuan dan teknologi

Dengan berkembangnya ilmu pengetahuan dan teknologi masyarakat menjadi lebih mudah dalam beraktivitas dan mendorong untuk berpikir lebih maju dan kehidupan sosial ekonomi lebih produktif, efektif, dan efisien sehingga membuat produksi dalam negeri mampu bersaing di pasar internasional.

c. Tingkat Kehidupan yang lebih Baik Dibukanya industri yang memproduksi alat-alat komunikasi dan transportasi yang canggih merupakan salah satu usaha mengurangi penggangguran dan meningkatkan taraf hidup masyarakat.

2. Dampak Negatif

a. Pola Hidup Konsumtif

Perkembangan industri yang pesat membuat penyediaan barang kebutuhan masyarakat melimpah. Dengan begitu masyarakat mudah tertarik untuk mengonsumsi barang dengan banyak pilihan yang ada. b. Sikap Individualistik

Masyarakat merasa dimudahkan dengan teknologi maju membuat mereka merasa tidak lagi membutuhkan orang lain dalam beraktivitasnya. Kadang mereka lupa bahwa mereka adalah makhluk sosial.

c. Gaya Hidup Kebarat-baratan

Tidak semua budaya Barat baik dan cocok diterapkan di Indonesia. Budaya negatif yang mulai menggeser budaya asli adalah anak tidak lagi hormat kepada orang tua, kehidupan bebas remaja, dan lain-lain.

d. Kesenjangan Sosial

Apabila dalam suatu komunitas masyarakat hanya ada beberapa individu yang dapat mengikuti arus globalisasi maka akan memperdalam jurang pemisah.

Kepada generasi dunia yang akan hidup pada abad mendatang perlu dibekali dengan penguasaan sains-teknologi dan spritual-keagamaan yang diharapkan dapat memecahkan berbagai permasahan kehidupan masyarakat dunia yang semakin kompleks. Selain pentingnya substansi kurikulum yang dapat menjawab tantangan zaman bagi generasi anak didik mendatang, tidak ada pilihan lain, kecuali pendidik/guru dalam proses pembelajran di sekolah perlunya mengedepankan kualitas tugas dan profesi yang diembangnya. Kehidupan masa depan membutuhkan penegetahuan dan keterampilan yang harus dimiliki anak didik yang akan hidup pada zaman berbeda dimana dunia senantiasa dinamis yang membutuhkan adaptasi (dengan pengetahuan dan keterampilan) pada era globalisasi. Sejalan dengan perkembangan sains-teknologi dan meluasnya pengaruh globalisasi, pendidik senantiasa dituntut agar mengimbangi perkembangan sains-teknologi yang terus berkembang.

\section{E. Tantangan Globalisasi}

Jemadu (2008: 310) tidak seorang pun dapat menghindari dari arus globalisasi. Setiap indivdu dihadapkan pada dua pilihan: "pertama, dia menempatkan dirinya dan berperan sebagia pemain dalam arus perubahan globalisasi, dan kedua, dia menjadi korban arus globalisasi". Arus globalisasi juga msuk dalam wilayah pendidikan dengan berbagai implikasi dan dampaknya. Dalam konteks ini, 
tugas dan peranan seorang pendidik/guru sebagai ujung otmbak dunia pendidikan di sekolah/madrasah sangat terdepan dalam menciptakan SDM yang dapat berkopetetif dengan generasi bangsa lain dalam suatu masyarakat dunia.

Selain dari masalah internal yang di hadapi masyarakat dan bangsa Indonesia di masa kritis dewasa ini, sekaligus pula masyarakat dan bangsa Indonesia memasuki milenium ketiga dengan tantangan-tantangan global yang semakin intensif. Kita tidak dapat menghindarkan diri dari tantangan-tantangan global tersebut. Tantangan global sekaligus membuka peluang-peluang bagi masyarakat dan bangsa Indonesia unuk terus hidup bahkan dapat meningkatkan taraf hidup.

Tantangan-tantangan tersebut antara lain kemejuan teknologi yang sangat pesat khususnya teknologi komputer, lahirnya kehidupan demokrasi yang semakin marak, pengakuan akan hak-hak asasi manusia, masalah gender, dan masalah kehidupan ekonomi baru sesudah Asia mengatasi kritis. Didalam menjawab kecenderungankecenderungan tersebut diperlukan suatu bentuk baru untuk dapat memberikan jawaban yang tepat terhadap lahirnya budaya global. Hanya dengan persiapan-persiapan yang baik Asia siap memasuki melenium ketiga yaitu memiliki sikap inovatif dan mau menanggung resiko yang terakumulasi. Dengan kedua sikap ini bangsa Asia dapat ikut serta di dalam kehidupan global yang semakin cepat dan semakin menyatu. Mengembang sikap inovatis yang merupakan salah satu kelemahan pendidikan di Asia termasuk Indonesia. Hanya bangsa Indonesia yang dapat memetik makna dari kehidupan global. Sebaliknya bangsa yang pendidikannya terus-menerus hanya memetingkan hafalan, menguji ujian multiple choice, menghapal rumus-rumus yang ruwet tapi tidak inovatif maka dia tidak dapat bersaing.

Dalam abad pasca kolonialisme selepas perang dunis II, bentuk-bentuk penjajahan politik sudah semakin berkurang di dunia, waluapun masih terjadi dalam skala kecil di beberapa belahan dunia. Namun demikian, tidaklah berarti bahwa kolonialisme dalam bidang-bidang lain seperti dalam bidang ekonomi, budaya, dan iptek juga surut dalam pencaturan dunia. Tamburaka (1999: 116) dengan demiakian tantangan lainnya bagi bangsa Indonesia adalah" munculnya koloniaisme di bidang iptek, menggantikan kolonialisme politik yang sudah semakin kecil skalanya, sejak tahun 1960-an". Baik negara berkembang yang sedang membangun ekonominya maupun negar-negara industri sama-sama memiliki kepentingan nasional yang mempengaruhi sikap dan kebijakan mereka dalam mengatasi isu lingkungan hidup global.

Jemadu (2008: 314) tantangan globalisasi yang harus diatisipasi pendidik dengan pentingnya mengedepankan profesinalisme yaitu:

1. Perkembangan ilmu penegetahuan dan teknologi yang begitu cepat dan mendasar. Dengan kondisi ini, seorang pendidik dihaarpkan dapat menyesuaikan diri dengan rensponsif, arif, dan bijaksana. Responsir artinya pendidikan harus bisa menguasai dengan baik produk iptek terutama yang berkaitan dengan dunia pendidikan, seperti pembelajaran dengan mengunakan multimedia. Tanpa penguasaan iptek yang baik, pendidik akan tertinggal dan menjadi korban iptek.

2. Krisis "moral" yang melanda negara dan bangsa Indonesia akibat pengaruh iptek dan globalisasi telah terjadi pergesaran nilai-nilai yang ada dalam kehidupan masyarakat. Nilai-nilai tradisional yang sangat menjunjung tinggi moralitas bisa saja dapat bergeser seiring dengan pengaruh iptek dan globalisasi.

3. Krisis sosial, seperti kriminalitas, kekerasan, pengangguran, dan kemiskinan yang terjadi di masyarakat dunia. Akibat perkembangan industri dan kapitalisme maka muncul masalahmasalah sosial yang ada dalam masyarakat tidak semua lapisan masyarakat bisa mengikuti dan menikmati dunia industri dan kapitalis.

4. Krisis identitas bangsa. Sebagai bangsa dan negara di tengah bangsa lain di dunia membutuhkan identitas kebangsaan (nasionalisme) yang tinggi dari warga negara Indonesia. Semangat nasinalisme tetap dibutuhkan eksisnya bangsa dan negara Indonesia. Nasionalisme yang tinggi dari warga negara akan mendorong jiwa berkorban untuk bangsa dan negara sehingga akan membuat prilaku positif dan terbaik untuk bangsa dan negara. 
5. Adanya perdagangan bebas, baik tingkat ASEAN, Asia pasifik, maupun dunia. Kondisi ini membutuhkan kensiapan yang matatng terutama dari segi SDM ayng andal dan unggul yang siap bersaing dengan bangsa-bangsa lain.

\section{KESIMPULAN \& SARAN}

Dari paparan di atas, sebagai kesimpulan adalah bahwa sebagai bangsa dan negara ditengah bangsa lain di dunia membutuhkan intentitas kebangsaan (nasionalisme) yang tinggi dari generasi muda Indonesia, seperti: Memiliki kemampuan untuk mengambil sikap yang bertanggung jawab sesuai dengan hati nuraninya, Memiliki kemampuan untuk mengenali masalah hidup dan kesejahteraan serta cara-cara pemecahannya, dan Memiliki kemampuan untuk memaknai peristiwa sejarah dan nilai-nilai budaya bangsa untuk menggalang persatuan Indonesia.

Semangat nasionalisme dibutuhkan tetap eksisnya bangsa dan negara Indonesia. Nasionalisme yang tinggi dari generasi muda sehingga akan membuat perilaku positif dan terbaik untuk bangsa dan negara. Dalam dekade terakhirnya, ada kecenderungan menipisnya jiwa nasionalisme dikalangan generasi muda.

\section{DAFTAR PUSTAKA}

Ali Muhammad. 2011. Pahlawan Nasional. Jogjakarta: Buku Biru

Dault, Adyaksa. 2003. Islam Dan Nasionalisme. Yayasan Amanah Daulatul Islam

Idi, Abdullah \& Safarina. 2011. Sosiologi pendidikan. Jakarta: Rajawali Pers

Jalaluddin, Idi, Abdullah. 2011. Filsafat Pendidikan. Jakarta: Rajawali Pers

Jemadu Aleksius. 2008. Citra Masyarakat Globalisasi. Jakarta: Sinar Harapan

Kaelan. 2010. Pendidikan Pancasila. Yogyakarta:Paradigma

Kazikame. 2013. Dampak Positif Dan Negatif Era Globalisasi

Nur Tirtaharja. 2001. Kebangkitan Nasionlisme Indonesia. Jakarta: Arya Ajisaka

Suparman. 2011. Globalisasi. Jakarta: Rineka Cipta

Tamburaka, Rustam. 1999. Pengantar Ilmu Sejarah Teori Filsafat Sejarah dan Iptek. Jakarta: Rineka Cipta
Yatim. 2001. Kewarganegaraan SMA. Jakarta: Erlangga. 